Justyna Moppert ${ }^{1}$, Katarzyna Zieniewicz-Cieślik', Małgorzata Tyczyno ${ }^{1}$, Matgorzata Sobolewska-Pilarczyk ${ }^{1,2}$ Matgorzata Pawłowska ${ }^{1,2}$

\title{
*THE FREQUENCY OF OCCURRENCE ANTI-HAV ANTIBODIES TO HEALTH EMPLOYEES - OWN OBSERVATIONS
}

\author{
*CZESTOŚĆ WYSTĘPOWANIA PRZECIWCIAŁ ANTY-HAV \\ U PRACOWNIKÓW SŁUŻBY ZDROWIA - OBSERWACJE WŁASNE
}

\begin{abstract}
${ }^{1}$ The Tadeusz Browicz Provincial Hospital for Infectious Diseases and Observation in Bydgoszcz
${ }^{2}$ Department of Infectious Diseases and Hepatology, Nicolaus Copernicus University in Toruń,

Ludwik Rydygier Collegium Medicum in Bydgoszcz

${ }^{1}$ Wojewódzki Szpital Obserwacyjno-Zakaźny im. T. Browicza w Bydgoszczy

${ }^{2}$ Katedra Chorób Zakaźnych i Hepatologii CM UMK w Bydgoszczy
\end{abstract}

\begin{abstract}
INTRODUCTION. In the years 1997-2016, Poland was counted among the countries with a low and very low endemicity of hepatitis A. Based on the epidemiological data from NIZP-PZH (National Institute of Public Health - National Institute of Hygiene), since 2017, an increase in the incidence of hepatitis A has been observed in Poland. Considering the low number of cases by 2016 and a high percentage of seronegative persons, an increased risk of HAV infections should be expected.

OBJECTIVE. The aim of the project was to assess the presence of anti-HAV IgG antibodies in the employees of the Provincial Hospital for Infectious Diseases and Observation in Bydgoszcz.

MATERIAL AND METHODS. The study was conducted on 123 people who are employees of the hospital. The presence of anti-HAV antibodies was detected using HAV IgG Elisa FORTRESS DIAGNOSTICS kits.

RESULTS. The presence of anti-HAV IgG antibodies was found in 28/123 (22.8\%) subjects. Anti-HAV IgG antibodies were almost exclusively found in people over 40 years of age. Only one case involved a younger person.

CONCLUSIONS. The low incidence of anti-HAV antibodies in the IgG class among medical personnel confirms the reasonableness of vaccinations against hepatitis A in this group.
\end{abstract}

Key words: viral hepatitis $A$, incidence, anti-HAV

\section{STRESZCZENIE}

WSTĘP. Polska w latach 1997-2016 r. była zaliczana do państw o niskiej i bardzo niskiej endemiczności wirusowego zapalenia wątroby typu A. W oparciu o dane epidemiologiczne NIZP-PZH, w Polsce od 2017 r. obserwuje się wzrost zapadalności na WZW A. Biorąc pod uwagę niską liczbę zachorowań do 2016 roku i wysoki odsetek osób seronegatywnych należy spodziewać się wzrostu ryzyka zakażeń HAV.

CEL. Celem projektu była ocena obecności przeciwciał anty-HAV IgG u pracowników Wojewódzkiego Szpitala Obserwacyjno-Zakaźnego w Bydgoszczy.

MATERIAŁ I METODY. Badania przeprowadzono u 123 osób będących pracownikami szpitala. Obecność przeciwciał ant-HAV wykrywano testem HAV IgG Elisa FORTRESS DIAGNOSTICS

WYNIKI. Obecność przeciwciał anty-HAV IgG stwierdzono u 28/123 (22,8 \%). Przeciwciała anty-HAV IgG stwierdzono u osób powyżej 40 r.ż. Tylko jeden przypadek dotyczył osoby młodszej.

WNIOSKI. Niska częstość występowania p/ciał anty-HAV w klasie IgG wśród personelu medycznego potwierdza zasadność szczepień p/WZW A w tej grupie.

Slowa kluczowe: wirusowe zapalenie watroby typu A, zapadalność, anty-HAV

* Report on XXI Assembly of the Polish Society of Epidemiology and Infectious Diseases, Bydgoszcz,20-22.09.2018 / Referat wygłoszony na XXI Zjeździe PTEiLChZ, Bydgoszcz, 20-22.09.2018

(C) National Institute of Public Health - National Institute of Hygiene / Narodowy Instytut Zdrowia Publicznego - Państwowy Zakład Higieny 


\section{INTRODUCTION}

By 1977, Poland was numbered among countries with a high incidence of viral hepatitis, assessed at about 250/100 thousand people. It is estimated that at that time the percentage of adults with anti-HAV IgG antibodies was close to $100 \%$ and was mostly the result of asymptomatic infections in childhood (1).

The years from 1978 to 1996 were a period of indirect endemicity with the annual number of cases up to 50,000. From 1997 to 2002, Poland was in the group of countries with a low endemicity of hepatitis A, and from 2003 to 2016, Poland was in the group of countries with a very low incidence, not exceeding $0.41 / 100$ thousand persons $(2,3,4)$. During that period, in 2008 there were 208 cases, and in 2009 - 652 cases of hepatitis A as well as an increase in incidence to $1.71 / 100,000$ people. This increase was highest in the group of people between 20 and 30 years of age. In the following years, the number of cases of hepatitis A ranged from between 35 to 155 a year. In 2017, there were 3072 cases of hepatitis A, and the incidence was 7.99 / 100 thousand people. Compared to the previous year, it was an 87 'fold increase; in 2016, there were 35 cases of hepatitis A, and the incidence was 0.09 / 100,000 people. The highest incidence in 2017 was recorded in the Wielkopolskie voivodeship (13.97 / 100 thousand people), Mazowieckie Voivodeship (12.95 / 100 thousand people), Sląskie voivodeship (11.99/ 100 thousand people), and Łódzkie voivodeship (10.48 / 100 thousand people) (5). In the Kujawsko-Pomorskie voivodeship, the incidence in 2017 amounted to 5.4 / 100,000 people.

At the Provincial Hospital for Infectious Diseases and Observation in Bydgoszcz in 2017, 69 people were hospitalized due to hepatitis A, including 11 children aged 4 to 17 years. Among the adults, infections in $95 \%$ of cases concerned men aged 21 - 49 years. By September 2018, the number of hospitalizations due to HAV infection was 60 , including 5 children. This year, $75 \%$ of infections occurred in men aged 22-47 years.

In the European Union countries, according to the ECDC (European Centre for Disease Prevention and Control) report, the most cases found in 2017 occurred in Great Britain, Germany, France, and Spain. These cases mainly concerned men aged $18-45$, with homosexual orientation (MSM, men who have sex with men) $(5,6,7)$. According to the data from the State Sanitary Inspector in Warsaw from January 2018, 95\% of cases registered in 2017 in the Mazowieckie voivodeship were men aged 20-44 (8). These infections may be associated with outbreaks of HAV in Europe among men having sexual contacts with men.

\section{WSTĘP}

Do 1977 r. Polska należała do krajów o wysokiej zapadalności na wzw typu A, ocenianej na około 250 $/ 100$ tys. Szacuje się, że w tym czasie odsetek osób dorosłych z obecnymi p/ciałami anty-HAV IgG wynosił blisko $100 \%$ i w większości był wynikiem zakażeń bezobjawowych przebytych w dzieciństwie (1).

Lata 1978 - 1996 to okres endemiczności pośredniej z roczną liczbą zachorowań do 50 tys. Od 1997 do 2002 r. Polska zaliczała się do grupy państw o niskiej endemiczności WZW A, w latach 2003 - 2016 do państw o bardzo niskiej zapadalności, nieprzekraczającej 0,41 / 100 tys. $(2,3,4)$. W tym okresie w roku 2008 odnotowano 208 przypadków, a w 2009 - 652 przypadki wzw typu A i wzrost zapadalności do 1,71/ 100 tys. Był on najwyższy w grupie osób między 20 a $30 \mathrm{r}$. ż. W następnych latach liczba zachorowań na wzw A wynosiła od 35 do 155 rocznie. W 2017 r odnotowano 3072 przypadki wzw A, a zapadalność wyniosła $7,99 / 100$ tys. W porównaniu do poprzedniego roku było to 87-krotnie więcej, gdyż w 2016 r zarejestrowano 35 przypadków WZW A, a zapadalność wynosiła 0,09/100 tys. Najwyższą zapadalność w 2017 r. odnotowano w województwie wielkopolskim $(13,97 / 100$ tys.), mazowieckim (12,95/100 tys.), śląskim (11,99/100 tys.) i łódzkim (10,48/100 tys.) (5). W województwie kujawsko - pomorskim zapadalność w 2017 r wyniosła $5,4 / 100$ tys.

W Wojewódzkim Szpitalu Obserwacyjno - Zakaźnym w Bydgoszczy w 2017 r. hospitalizowano z powodu wzw A 69 osób, w tym 11 dzieci w wieku od 4 do 17 lat. Wśród dorosłych zakażenia w 95\% przypadków dotyczyły mężczyzn w wieku 21-49 lat. Do września 2018 r liczba hospitalizacji z powodu zakażenia HAV wynosiła 60 , w tym 5 dzieci. W tym roku $75 \%$ zakażeń dotyczyło mężczyzn w wieku 22-47 lat.

W krajach Unii Europejskiej zgodnie z raportem ECDC (Europejskiego Centrum ds Zapobiegania i Kontroli Chorób) w 2017 r. najwięcej zachorowań stwierdzono w Wielkiej Brytanii, Niemczech, Francji i Hiszpanii. Zachorowania te dotyczyły głównie mężczyzn w wieku od 18 - 45 lat, o orientacji homoseksualnej (ang. MSM, men who have sex with men) $(5,6,7)$. Wg danych Państwowego Wojewódzkiego Inspektora Sanitarnego w Warszawie ze stycznia 2018 r. 95 \% zachorowań zarejestrowanych w $2017 \mathrm{r}$ w województwie mazowieckim stanowili mężczyźni w wieku od 20 - 44 lat (8). Zakażenia te mogą być powiązane $\mathrm{z}$ występującymi w Europie ogniskami zakażeń HAV wśród mężczyzn mających kontakty seksualne z mężczyznami.

\section{CEL}

Celem projektu była ocena obecności przeciwciał anty-HAV IgG u pracowników Wojewódzkiego Szpitala Obserwacyjno - Zakaźnego w Bydgoszczy. 


\section{OBJECTIVE}

The aim of the project was to assess the presence of anti-HAV IgG antibodies in the employees of the Provincial Hospital for Infectious Diseases and Observation in Bydgoszcz.

\section{MATERIAL AND METHODS}

The study was conducted on 123 people (109 women and 14 men aged from 26 to 79 years), including 29 doctors, 67 nurses, 11 laboratory employees, and 16 people from the administration. The presence of antiHAV antibodies was detected using HAV IgG Elisa FORTRESS DIAGNOSTICS kits.

\section{RESULTS}

In 95/123 (77.2\%) subjects, no anti-HAV antibodies in the IgG class were detected in the serum, in 28/123 $(22.8 \%)$ subjects the presence of anti-HAV IgG antibodies was found. Among people with anti-HAV IgG antibodies there were 7 doctors (aged 63-79), 12 nurses (33-62 years old), 6 laboratory workers (47-70 years old), and 3 administration employees aged 45, 47 and 55. Anti-HAV antibodies were detected on average 2.5 times more often in laboratory employees than in doctors or nurses (Table I). Anti-HAV antibodies have also been found in people over 40 years of age. Only one case concerned a younger person (nurse, 33 years old) (Table II).

\section{DISCUSSION}

By 1977, the highest incidence of hepatitis A in Poland would occur among children under the age of 8. The number of registered cases was 50-85 thousand a year. In the years 1978-1996, in the period of indirect endemicity, the disease mainly affected children and adolescents aged between 10 and 14. The years from 1997 to 2016 are a time of low and very low endemicity, a time in which transmission of the peak of incidence to older age groups over the age of 25 was observed (1). In 2009, there was a periodic increase in incidence mainly in men aged between 20 and 40 years (9). Since 2017, the incidence of hepatitis A has been increasing.

Tourist trips to countries with a high or indirect endemicity of HAV incidence are the cause of additional disease cases. By 2014, infections brought from countries such as Egypt, Algeria, and Morocco prevailed. Since 2015, the number of cases brought from Ukraine has also increased (2).

The epidemiological situation in Europe and the world affects the number of cases of hepatitis $\mathrm{A}$ in Poland.

\section{MATERIAŁ I METODY}

Badania przeprowadzono u 123 osób (109 kobiet i 14 mężczyzn w wieku od 26 do 79 lat), w tym 29 lekarzy, 67 pielęgniarek, 11 pracowników laboratorium i 16 osób z administracji. Obecność przeciwciał anty-HAV wykrywano testem HAV IgG Elisa FORTRESS DIAGNOSTICS.

\section{WYNIKI}

U 95/123 (77,2 \%) badanych nie wykryto w surowicy obecności anty-HAV w klasie IgG, u 28/123 $(22,8 \%)$ stwierdzono obecność anty-HAV IgG. Wśród osób z obecnymi p/ciałami anty-HAV IgG było: 7 lekarzy (w wieku 63-79 lat), 12 pielęgniarek (33-62 lata), 6 pracowników laboratorium (47-70 lat) i 3 pracowników administracji w wieku 45, 47 i 55 lat. Przeciwciała anty-HAV wykrywano średnio 2,5-krotnie częściej u pracowników laboratorium niż lekarzy czy pielęgniarek (Tab. I). Przeciwciała anty-HAV stwierdzono u osób powyżej 40 r.ż. Tylko jeden przypadek dotyczył osoby młodszej (pielęgniarka, 33 lata) (Tab. II).

Table I. The presence of anti-HAV antibodies among hospital staff.

Tabela I. Obecność p/ciał anty-HAV wśród personelu szpitalnego.

\begin{tabular}{|c|c|c|c|c|}
\hline \multirow{2}{*}{ staff } & \multicolumn{2}{|c|}{$\begin{array}{c}\text { positive } \\
\text { anti-HAV }\end{array}$} & \multicolumn{2}{c|}{$\begin{array}{c}\text { total number of } \\
\text { subjects }\end{array}$} \\
\cline { 2 - 5 } & $\mathbf{n}$ & $\%$ & $\mathbf{n}$ & $\%$ \\
\hline doctors & 7 & 24.1 & 29 & 100 \\
\hline nurses & 12 & 17.9 & 67 & 100 \\
\hline $\begin{array}{c}\text { aboratory } \\
\text { employees }\end{array}$ & 6 & 54.5 & 11 & 100 \\
\hline $\begin{array}{c}\text { administrative } \\
\text { employees }\end{array}$ & 3 & 18.75 & 16 & 100 \\
\hline
\end{tabular}

Table II. The presence of anti-HAV antibodies among hospital staff according to age.

Tabela II. Obecność p/ciał anty-HAV wśród personelu szpitalnego w przedziałach wiekowych.

\begin{tabular}{|c|c|c|c|c|c|c|}
\hline \multirow{2}{*}{ age range } & $\begin{array}{c}\text { positive } \\
\text { anti-HAV }\end{array}$ & $\begin{array}{c}\text { negative } \\
\text { anti-HAV }\end{array}$ & \multicolumn{2}{|c|}{ total } \\
\cline { 2 - 7 } & $\mathrm{n}$ & $\%$ & $\mathrm{n}$ & $\%$ & $\mathrm{n}$ & $\%$ \\
\hline < 40 years old & 1 & 3,4 & 28 & 96,6 & 29 & 100 \\
\hline 40-50 years old & 11 & 25,6 & 32 & 74,4 & 43 & 100 \\
\hline 50-70 years old & 13 & 27,1 & 35 & 72,9 & 48 & 100 \\
\hline < 70 years old & 3 & 100 & 0 & 0 & 3 & 100 \\
\hline
\end{tabular}

\section{DYSKUSJA}

Do 1977 r. najwyższa zachorowalność na WZW A w Polsce występowała wśród dzieci poniżej 8 r.ż. Liczba rejestrowanych przypadków wynosiła $50-85$ tys. 
In recent years, there have been outbreaks of HAV infection of international range. Food can be a source of these infections; in 2012, for example, in the Netherlands, an epidemic was registered after the consumption of frozen strawberries. Between January 2013 and August 2014, 1589 cases of HAV infection were recorded in Europe, including Poland, resulting from the consumption of frozen soft fruits.

Another common source of HAV infections is risky sexual behaviour. In Europe, between June 2016 and May 2017, there were outbreaks of HAV infections among MSM (men who have sex with men) communities in Great Britain, Spain, and France $(6,10)$. At the same time, in Poland in the Mazowieckie voivodeship, according to data from the State Sanitary Inspector in Warsaw, 95\% of cases of hepatitis A were related to men aged 20-44. This may confirm that the European outbreak has also included the MSM groups in Poland.

The most effective form of protection against the illness is an active prophylaxis. The effectiveness of vaccination is high and concerns both a pre- and post-exposure prophylaxis. There have been reports that confirm obtaining of a high titre of anti-HAV IgG antibodies in patients $<40$ years old faster after the first dose of vaccination, indicating at the same time a satisfactory immune response in older patients $(11,12)$. The effectiveness of inactivated hepatitis A vaccines has been confirmed in vaccination programs, among other countries, in Israel, where vaccination included children aged 18 months (first dose) and 24 months (booster). The program showed that vaccinating $3 \%$ of the population annually significantly reduces the number of HAV infections in all age groups (13).

Due to the many years of intermediate and low endemicity and the low number of people vaccinated against hepatitis A, it is estimated that the Polish population is mostly sensitive to HAV infection.

In the present own study, anti-HAV IgG antibodies were found in only one person under 40 years of age. In groups of people between 40 and 50 and between 50 and 70 years of age, the presence of anti-HAV IgG antibodies was detected in $25.6 \%$ and $27.1 \%$ of subjects, respectively. Among three people over 70 years of age anti-HAV antibodies were present in each of them. A similar increase in seroprotection with increasing age was observed in the study by Juszczyk et al. (14). In a study carried out in the Wielkopolska Region (Greater Poland) in 2009-2015 by M.Bura, et al., the percentage of patients with anti-HAV antibodies was higher in older age groups (15) which confirmed a greater susceptibility to infection in patients up to 40 years of age. Similar conclusions were shown in the presented study, in which the presence of anti-HAV IgG antibodies was found among people over 40 years of age. This is a typical population distribution of anti-HAV IgG antibodies for countries whose endemicity has changed from intermediate to low (4). Therefore, the rocznie. W latach 1978 - 1996, w okresie endemiczności pośredniej, zachorowania dotyczyły głównie dzieci i młodzieży w wieku między 10 - 14 r.ż. Lata 1997 - 2016 to czas endemiczności niskiej i bardzo niskiej, w którym obserwowano przeniesienie szczytu zachorowań na starsze grupy wiekowe powyżej 25 r.ż. (1). W roku 2009 odnotowano okresowy wzrost zapadalności głównie u mężczyzn między 20 a 40 r.ż (9). Od 2017 roku stwierdza się wzrost zapadalności na WZW A.

Wyjazdy turystyczne do krajów o wysokiej lub pośredniej endemiczności występowania zakażeń HAV są przyczyną zachorowań przywlekanych. Do 2014 r. przeważały zakażenia przywleczone $\mathrm{z}$ takich krajów jak Egipt, Algeria, Maroko. Od 2015 roku zwiększa się także liczba przypadków przywlekanych z Ukrainy (2).

Sytuacja epidemiologiczna w Europie i na świecie ma wpływ na liczbę zachorowań na wzw A w Polsce.

W ostatnich latach obserwuje się ogniska zakażenia HAV o zasięgu międzynarodowym. Źródłem zakażeń może być żywność. W 2012 r. w Holandii zarejestrowano ognisko epidemii po spożyciu mrożonych truskawek. Między styczniem 2013 roku a sierpniem 2014 notowano w Europie, w tym również w Polsce, 1589 przypadków zakażenia HAV będących skutkiem spożycia mrożonych owoców miękkich.

Innym źródłem zakażeń HAV są ryzykowne zachowania seksualne. W Europie między czerwcem 2016 a majem 2017 r. stwierdzono ogniska zakażeń HAV wśród społeczności MSM (ang. men who have sex with men) w Wielkiej Brytanii, Hiszpanii i Francji $(6,10)$. W tym samym czasie w Polsce w województwie mazowieckim, wg danych Państwowego Wojewódzkiego Inspektora Sanitarnego w Warszawie, 95\% zachorowań na wzw A dotyczyło mężczyzn w wieku 20 - 44 lat. Może to potwierdzać, że ognisko europejskie swym zasięgiem objęło także grupy MSM w Polsce.

Najbardziej efektywną formą ochrony przed zachorowaniem jest profilaktyka czynna. Skuteczność szczepień jest wysoka i dotyczy zarówno profilaktyki przed- jak i poekspozycyjnej. Istnieją doniesienia, które potwierdzają szybsze osiąganie wysokiego miana $\mathrm{p} /$ ciał anty-HAV IgG u pacjentów < 40 r.ż. po I dawce szczepienia, zwracając jednocześnie uwagę na osiągnięcie zadowalającej odpowiedzi immunologicznej u pacjentów starszych $(11,12)$. Efektywność inaktywowanych szczepionek przeciwko wzw A potwierdzono w programach szczepień m.in. w Izraelu, gdzie szczepieniem objęto dzieci w wieku 18 miesięcy (I dawka) i 24 miesięcy (dawka przypominająca). W programie tym wykazano, że zaszczepienie $3 \%$ populacji rocznie znacznie zmniejsza liczbę zakażeń HAV we wszystkich grupach wiekowych (13). 
promotion of vaccination against hepatitis $\mathrm{A}$, which since 1990 is available in Poland as part of the recommended vaccinations, is clearly justified.

\section{CONCLUSIONS}

The low incidence of anti-HAV antibodies in the IgG class among medical personnel and the current epidemiological situation in Poland confirms the reasonability of vaccinations against hepatitis $\mathrm{A}$ in this group.

\section{REFERENCES}

1. Magdzik W., Czarkowski M. Zmiany w endemiczności wirusowego zapalenia wątroby typu A (WZW A) w Polsce. Przegl Epidemiol 2004; 58: 355-60

2. Polański P. Wirusowe zapalenie wątroby typu A w Polsce w 2015 roku. Przegl Epidemiol 2017; 71(3): 345-349

3. Baumannn - Popczyk A. Wirusowe zapalenie wątroby typu A w Polsce w 2010 roku. Przegl Epidemiol 2012; 66: 273-76.

4. WHO position paper on hepatitis A vaccines (June 2012). Weekly Epidemiol Record, 2012; 87 (28/29): 261-76

5. European Centre for Disease Prevention and Control;Epidemiological update: Hepatitis A outbreak in the EU/ EEA mostly affecting men who have sex with men.12 wrzesień $2018 \mathrm{r}$.

6. Ndumbi P. Hepatitis A outbreak disproportionately affecting men who have sex with men (MSM) in the European Union and European Economic Area, June 2016 to May 2017.

7. Rodriguez - Tajes S. Hepatitis A outbreak in Barcelona among men who have sex with men (MSM), January June 2017: A hospital perspective Liver Int. 2018 Apr; 38 (4): 588-593.

8. Stan zachorowań na wirusowe zapalenie wątroby typu A w województwie mazowieckim. [online]http://wsse. waw.pl/aktualnosci-i-komunikaty/komunikaty/stan-zachorowan-na-wirusowe-zapalenie-watroby-typu-a-w-wojewodztwie-mazowieckim [dostęp: 04.01.2018 r.].

9. Baumann - Popczyk A. Wirusowe zapalenie wątroby typu A w Polsce w 2009 roku. Przegl Epidemiol 2011; 65: 255-258.

10. Ognisko WZW A wśród mężczyzn mających kontakty seksualne z mężczyznami w Europie i Polsce [online] http://www.pzh.gov.pl/ognisko-wzw-a-wsrod-mezczyzn-majacych-kontakty-seksualne-z-mezczyznami-w-europie-i-i-w-polsce [dostęp:28.07.2017r.].

11. Van Der Meeren O, Crasta P, de Ridder M. A retrospective pooled analysis assessing the effect of age on the immunogenicity of Havrixin healthy adults. Hum VaccinImmunother 2015;11:1729-1734.

12. CDC Update: Prevention of hepatitis A after exposure to hepatitis A virus and in international travelers. Updated Recommendations of the Advisory Committee on Immunization Practices (ACIP). MMWR Weekly, 2007; 56: $1080-1084$
W związku z wieloletnim okresem endemiczności pośredniej i niskiej oraz małą liczbą osób szczepionych przeciwko wzw A szacuje się, że populacja polska jest w większości wrażliwa na zakażenie HAV.

W badaniu własnym przeciwciała anty-HAV $\mathrm{IgG}$ stwierdzono tylko u jednej osoby poniżej 40 r.ż. W grupach osób między 40 a 50 oraz między 50 a 70 r.ż obecność p/ciał anty-HAV IgG wykryto odpowiednio u 25,6 \% i 27,1 \% badanych. Wśród trzech osób powyżej 70 r.ż. przeciwciała anty-HAV były obecne u każdej z nich. Podobny wzrost seroprotekcji wraz z wiekiem zaobserwowali w swoim badaniu Juszczyk i wsp. (14). W badaniu przeprowadzonym w Wielkopolsce w latach $2009-15$ przez M.Bura i wsp. odsetek pacjentów z obecnymi p/ ciałami anty-HAV był wyższy w starszych grupach wiekowych (15), co potwierdzało większą podatność na zakażenie pacjentów do 40 r.ż. Podobne wnioski wykazano $\mathrm{w}$ prezentowanej pracy, w której obecność p/ciał anty-HAV IgG stwierdzono wśród osób powyżej 40 r.ż. Jest to typowy populacyjny rozkład obecności przeciwciał anty-HAV IgG dla państw, w których endemiczność uległa zmianie z pośredniej na niską (4). Dlatego propagowanie szczepień p/ko wzw A, które od 1990 r. są w Polsce dostępne w ramach szczepień zalecanych, jest uzasadnione.

\section{WNIOSKI}

Niska częstość występowania p/ciał anty-HAV w klasie IgG wśród personelu medycznego i aktualna sytuacja epidemiologiczna w Polsce potwierdza zasadność szczepień p/wzw A w tej grupie.

13. Dagan R, et al. Incidence of hepatitis A in Israel following universal immunization of toddlers. JAMA: 2005, 294:202-210.

14. Juszczyk G., et al. Immunity to hepatitis A virus among working professionals in Poland - Result of 3 -year serological survey 2013 - 2015. Ann Agric Environ Med 2018; 25 (3): 572-575.

15. Bura M, et al. Seroprevalence of hepatitis A virus antibodies (anti-HAV) in adult inhibitants of Wielkopolska region, Poland - the role of simple demographic factors. Ann Agric Environ Med 2012;19 (4):738-741.

Received: 7.11.2018

Accepted for publication: 15.11.2018

Otrzymano: 7.11.2018 r.

Zaakceptowano do publikacji: $15.11 .2018 \mathrm{r}$.

\section{Address for correspondence:}

Adres do korespondencji:

Lek. med. Justyna Moppert

Klinika Chorób Zakaźnych i Hepatologii Wieku

Rozwojowego CM UMK

Ul. Św. Floriana 12, 85-030 Bydgoszcz

Tel. 523255600

e-mail:j_slagowska83@o2.pl 